\title{
The Ecological Wisdom of Melus Tribe in the Novel Mata di Tanah Melus by Okky Madasari
}

\author{
Lina Dwi Yulianti, Herman J Waluyo, Nugraheni EkoWardhani
}

Postgraduate Program of Indonesian Language Education, SebelasMaret University, Surakarta, Indonesia

Received: 01 Oct 2021; Received in revised form: 03 Nov 2021; Accepted: 11 Nov 2021; Available online: 19 Nov 2021

(C2021 The Author(s). Published by Infogain Publication. This is an open access article under the CC BY license

(https://creativecommons.org/licenses/by/4.0/).

\begin{abstract}
Melus tribe is believed to be one of the first tribes to inhabit Belu area of East Nusa Tenggara. Melus tribe never wanted to accept renewal like what is happening today, so the customs that are in it are still supported. In this regard, this study aims to describe (1) ecological wisdom in the values of Melus tribe described in the novel, (2) the role of the environment in Melus tribe such as the physical background. This research is descriptive qualitative research, using content analysis method. The data in this study were sourced from literature studies. Therefore, it can be concluded that the novel Mata di Tanah Melus has a story about the components of a power and environment that can be reintroduced. This ecological wisdom can offer a new relation between literature and nature, which is then used as a creative process or material in the creation of a literary work with the theme of saving the environment or nature.
\end{abstract}

Keywords-Ecological Wisdom, Melus Tribe, Novel.

\section{INTRODUCTION}

Climate change has an indirect impact on human life. [1] Environmental damage is allegedly contributing to climate change. This climate change often occurs due to human activities such as urbanization, deforestation, industrialization, and by natural activities such as continental drift, volcanic eruptions, changes in the earth's orbit around the sun, sun spots and El-Nino.In addition, humans have begun to develop science and technology by creating new discoveries, which without realizing it have contributed a lot to activities that are part of destroying the environment. The new civilization does not only destroy the environment, but also destroys the continuity of life that exists between humans and nature itself. While humans can never be separated from the existence of nature. Because with nature, humans can fulfill their needs, therefore humans should do things that can protect the natural environment.

Problems and ways to protect the environment have now entered in various scientific fields. Especially in the field of literature.[2]stated that literary works are the result of imitation and creation.It is from this imitation process that environmental issues can be raised in a literary work. Many writers in the field of literature try to offer an inspiration and an invitation in terms of saving the earth.To create a good relation between nature and humans themselves.[3]stated that literature has a role in inspiring humans to do better and be sensitive to natural health.Literature supplies an overview and direction contained in the culture that society has made into a habit or in other words a tradition [4]. The explanation above describes the influence of literature on a change that occurs in society, especially changes to support and protect the ecology around it.

Ecocriticism is an earth- or environmentalcentered approach to literature [5]. In line with Garrard's opinion, ecocriticism is the development of a science about criticizing the existing conditions in the environment regarding the study of literature [6]. Regarding nature, ecocriticism can be used to criticize and decide what humans can and cannot do when they are in nature, as well as when they are protecting nature from being damaged. 
In the ecocritical view, humans and nature are not seen as separate and contradictory identities, but humans themselves are considered part of nature.The nonhuman environment is not an object to be overexploited for the sake of humans, so humans must be able to protect and support harmony with the environment.Because humans and their environment are one unit in an ecological system. In an ecological context, ecocriticism can help define, explore, and even solve ecological problems by turning scientific problems in the realm of ecology into more general problems[5]. This study aims to find the form or value of the ecological wisdom that exists in a society.

Ecological wisdom can contain policies regarding environmental management [7]. Ecological wisdom is evidence of explicit knowledge, originating and developing from diverse philosophical, cultural, and disciplinary backgrounds and across generations. Treating ecological wisdom as a process that produces information and guidance on how social and ecological processes that produce flows between human components and ecosystems naturally[8]. According to [9]ecological wisdom is a form of movement for social justice, peace, and forms of ecological responsibility (such as freedom from injustice, from war and violence, and the destruction of the natural environment).

One part of literary works that can be used to express a form of caring in protecting nature is the novel. Because the novel is one form of literary work that is of interest and is easily enjoyed by various groups and ages.In literature, especially novels, problems that exist in the environment and nature can be seen in the background which is part of the elements that cannot be separated from the characters, the language commonly used in conveying a story, and can support the overall meaning from a novel.

One of the novels that talk about events in the environment in an area is the novel Mata di Tanah Melus. This novel has a description of how Melus community or tribe supports and respects the natural environment that surrounds them. Keeping the values that have been passed down by the ancestors. Where this novel features a small child, named Mata. Mata is a child with a good attitude so he was chosen to be part of Melus tribe.Instead, Mata was not allowed to leave Melus tribe, but Mata refused and tried to leave the world of Melus tribe. Even though the natural beauty presented there is remarkably interesting and Mata felt it for the first time.

Seeing the explanation above, it proves how important it is to know the form of the ecological wisdom of a community or an ethnic group.With this, we know that it can be applied either in its entirety or selected and adapted to the current situation. The application of procedures for protecting the environment, to create a harmonious relationship between humans and nature.

\section{METHOD}

This research is qualitative descriptive research, the data is sourced from literature study. The data from this study are excerpts from stories in the novel Mata di Tanah Melus which are in the form of paragraphs, sentences that explain the values of ecological wisdom and the role of the environment such as the physical background that exists in Melus tribe.

The steps used in this research are to read and understand the novel completely. This is done so that researchers can understand the contents of the novel in more depth.The source of the research data is the novel Mata di Tanah Melus by OkkyMadasari. The analysis of this research is carried out by reading critically, analytically, and understanding more deeply so that it can obtain total results for collecting data needed by researchers.

\section{RESULTS ANDDISCUSSION}

Ecological wisdom is a form of social conditions and the responsibility of individuals and groups to the ecology or environmental conditions around them. The form of responsibility carried out by Melus tribe in this novel is told by OkkyMadasari through the life circumstances of Melus tribe in Belu, East Nusa Tenggara. The following is a form of ecological wisdom in Melus tribe described by OkkyMadasari through the novel Mata di Tanah Melus:

\subsection{Ecological Wisdom in the values of Melus Tribe}

Ecology is the study of the relation between humans and the environment. Ecology is also indirectly part of culture because humans themselves are part of the actors of that culture. Interrelated because culture is a part of the cultural system. The cultural system will form a human group or a certain group of people with values to make it the identity of the group.

Melus tribal community still prioritizes the values that are applied in their lives to be able to protect nature. The values that are still firmly held by Melus tribe include moral values, social values, and trust values. Like the quote below.

"It wasn't me who hit the cow! The driver of the car we rented that crashed. In fact, I have already paid a fine of twenty million." (Ma- 


$$
\text { ta,2018:51) }
$$

The quote above illustrates that there are consequences when you make a mistake that destroys nature. According to [10] humans are obliged to respect the rights of all living things to exist, live, grow, and develop naturally in accordance with the purpose of their creation. Because in the culture of Melus people, when an animal dies unnaturally or because it is hit, the person crashing it must pay the customary fine that applies in the area. Because their cows there are free to be wild to find their own food. [11]stated in general, traditional communities armed with local knowledge capital, such as local biological knowledge has been able and successful in protecting potential ecological processes, protecting various species or varieties of plants and animals, and their ecosystems, for the benefit of their local economy in a sustainable manner. Indirectly, paying the customary fine can be interpreted as compensation to the animal owner because the livestock is dead and cannot be sold anymore.In addition, there is also an assumption that if something happens to the cow, that it is believed by Melus tribe that it will bring bad luck to the life of the person who hit into it and is not responsible, so they must hold a ceremony. Like the quote below.

"I'd better do the ceremony. Let calm the spirit. May you be safe and blessed during your journey here, as well as your life forever." (Mata,2018:51)[12].

The belief that animals are important makes Melus people who make mistakes or make animals die, must hold a traditional ceremony to make the animal's spirit calm. And so that the person who made the mistake can continue his life.Even though they have paid the fine, it still feels like those who violate the rules must carry out the ceremony. Because that is the belief that people believe there. Of course, as people who do not know the customs of a new place to visit, we must follow what has been carried out there. Because Indonesia has remarkably diverse customs and cultures in each region. So, each region has its own rules and must be followed.

\section{"Lakaan Mount for us is a heritage that must be preserved. For us, what is in Lakaan Mount is honor and power." (Mata, 2018:112)}

In carrying out ceremonial activities, of course, a community has a special place, which is considered sacred and has its own power. As in the quote above, Lakaan Mount is made as a symbol of a mountain that has its own strength and honor for Melus tribal community. So that makes Lakaan Mount used as a place to carry out traditional activities. DE (Deep Ecology) theory in [10] $\mathrm{Hu}-$ mans are also required to appreciate and respect non-living objects, because all objects in the universe have the same rights to exist, live and develop. From this explanation, it can be understood that objects in nature such as mountains also have their own strengths.Although scientifically mountains are activities from within the earth, but what circulates in the community around each mountain has its own story, and we as Indonesians who have various cultures, must respect each other, and protect the environment.Because it is often found, that mountains are a habitat for rare animals for shelter, rare plants, so the assumption that mountains have power and honor is certainly true.

\section{"We worship many things. We worship all the forces of nature." (Mata, 2018:159). \\ "We have to save the God of Crocodile!" (Mata, 2018:159)}

[13]stated that culture is a living heritage or creation of a community created or the result of the creativity of supporters so that they can interact with their ecology. The quote above is also a strong proof that Melus people believe that nature has unexpected powers. They will be afraid, if they violate the rules that exist in nature it will get them into trouble. Interacting with ecology is certainly especially important, because with the preservation of the ecosystem system that exists in nature, life will feel extremely comfortable and safe.In addition, the assumption that animals are gods, in fact crocodiles are predatory animals that are feared by many other animals, because crocodiles prey on secretly from the water.In the story Melus tribe saved the God of Crocodile because in the Crocodile story there always preyed on humans who had bad intentions, so when the humans rested quietly on the riverbank, the crocodiles secretly preyed on the humans.

\subsection{Environmental Role (Physical Background)}

In connection with ecological wisdom with literary works, it can be described that the environment (physical background) has a role in the storyline of the novel Mata di Tanah Melus. The ecological view suggests that the existence of organisms is influenced by the environment or there is a reciprocal and interrelated relation between organisms and their environment[3]. The environment can be said as an external factor that can affect the growth, development, and life of an organism. Because ecology in the scope of literary works is a form of an ecosystem that can have an influence in it.

Mata di Tanah Melusis a novel that talks about the life of Melus tribe who live in Belu, West Nusa Tenggara. whereMelus tribe is told to live in a savanna and to enter the area is exceedingly difficult because they are hidden and it is not easy to reveal their community life. The following is the form of the environment (physical background) of Melus tribe.

"Vacant lands stretch along the main road. The 
houses are small, built with simple boards or makeshift walls." (Mata, 2018:32).

The quote describes how the environmental conditions in Melus tribe are, where their environment is still a lot of vacant land. The houses are also made with simple and makeshift walls.From this it can be illustrated that Melus people really take care of the environment by building a simple and modest house because that way they do not have to take a lot of what is in nature and of course this can support harmony between humans and nature itself.

"We have already passed the main door. There is a space that is not too wide with large trees that are not too close together." (Mata,2018:66)

It is clearer from the quote above that the house of Melus tribe can also have the concept of a house in which there are large trees. Although their house looks quite simply but if there is a tree in the house, of course this can add a beautiful impression to people who see it.Moreover, the tree in this house can give the impression that the situation in the house is very peaceful with the presence of trees in the house, of course, it can also supply additional oxygen for the occupants of the house.In addition, trees can also supply aromatherapy coolness and increase productivity for their owners, besides that, of course, they can also be used for the needs or needs needed in the owner's life.

"I woke up on a rock formation, under a roof made of dry weeds in the shape of a cone, in a house made of logs that formed a circular wall. The floor of the house is made of small stones that are artfully arranged." (Mata, 2018: 80).

The quote above explains the shape of the house picture of Melus tribe which is very much integrated with nature. Where the house is a place to rest, interact with family. Exploration of architectural phenomena that leads to knowing the symbolic meaning contained in it needs to be done through a lengthy process. This is carried out because the symbolic meaning and philosophical values of the local culture have been inherently integrated or compounded with the building [14]. In this quote, the setting of the house describes the shape of the physical background to flow an event or events that are happening in the story. The houses of Melus tribe are remarkably diverse, if at the beginning there was a tree in the house. It turns out that this quote further explains the picture inside the house of Melus tribe. The bed is made of stone arranged neatly, the roof is made of dry thatch in the shape of a cone, the floor of the house is also made of small stones arranged neatly. This, of course, is increasingly convincing that Melus tribe is highly creative and can use materials that exist and are available in nature. They make beneficial use of it, so that their houses look unique and interesting for new people to see.

\begin{abstract}
"At the end of the courtyard, facing all the plants, was a house made of cactus walls. Only the doors and windows are made of wood. The rest are all big, green, prickly cacti." (Mata,2018:125)
\end{abstract}

The quote above explains that there is a house from Melus tribe that has walls made of cactus plants, doors and windows made of wood.[14]The existence of residential buildings scattered in the archipelago which for centuries has been present and has left a long trail both culturally and socially and integrated into the lives of the people whose owners have a wealth of extraordinary local wisdom values. This explanation proves that the existing houses or houses made by Melus tribe all come from nature and have their own uniqueness. Even though they use materials from nature, they do not use them excessively, they always protect nature by uniting their homes with what has been supplied or what is in nature. So that they do not destroy nature and they can take shelter from the wind and rain and can gather with their families without having to fear when it rains or the night wind. Because the house is actually a place to take refuge and chat with loved ones, even though the house is only made of varied materials, the most important thing is the comfort that the occupants of the house get.

\section{"He dropped me in the middle of a field, a meadow that was all green and almost border- less, as was the scene I saw this morning, which made me tempt to leave Mama until finally trapped in this place." (Mata, 2018:85)}

The next physical background is the field. This field is usually used to gather to carry out community activities together. In this novel, the field is used to gather when there is an important activity such as holding a big event.In addition, the field in this novel is described as having a green view and is very pleasing to the eye when looking around it. In this case, as if to give a message, that from the field, we can see how wide and green the environment of Melus tribe is. So that it can make people stunned when they see what is presented before their eyes. This means that it illustrates that Melus tribal community is incredibly careful about their environment so that people who see it do not want to leave Melus tribal environment and use nature to captivate the hearts and eyes of those who manage to enter Melus tribal environment.Because it is told in the novel, to enter the environment of Melus tribe only people who have good intentions can see how the environment of Melus tribe itself is.

\section{CONCLUSION}


Based on the results of the discussion above, it can be concluded that the ecological wisdom that exists in Melus tribal community is an interaction relation that occurs between humans and the nature around them. This ecological study of literature on nature supplies an overview of the values that exist in society, namely sociocultural values. Where the socio-cultural value in this novel is strongly emphasized in case of a person hitting a cow with his car and being held accountable or a customary fine for making the livestock die. Then the impact of the death of the livestock, makes the person in charge must pay a fine, besides that the person in charge must also perform a traditional ceremony. Because when they do many activities, they still dream of meeting a cow again. In addition, many of the beliefs of Melus people were finally known, namely they believed in the power that exists in nature.

The role of the environment (physical background) has its own role, because with this role it can help the plots or the course of a story in the novel Mata di Tanah Melus. Overall, the setting used in this novel depicts a field or a savanna-like area, as we know the setting where the story of this novel is inBeliu, East Nusa Tenggara. Where this expanse of land can make people captivated by the situation there. In addition, houses are made and blended from materials that exist in nature. It adds to the impression that the environment there is in a field.In addition, there are also forms of physical background, houses made of cactus and roofs of dry grass. As is known, cactus and dry weeds are like identical or typical plants from the savanna area.Because these plants can grow well even though they are not exposed to water too often, because this savanna area has less rainfall than other areas.

\section{ACKNOWLEDGEMENTS}

Thanks to Prof. (Em) Dr. Herman J. Waluyo, M.Pd. and Dr. NugraheniEkoWardhani, M. Hum., who have helped in directing and guiding from the beginning of the research to the end of this research. Thanks also to the editorial team and the journal team for giving us an opportunity to publish our research.

\section{REFERENCES}

[1] Julismi, "Dampak Dan Perubahan Iklim Di Indonesia," $J$. Geogr., vol. 5, no. 1, pp. 39-46, 2013.

[2] A. Teuww, Sastra dan Ilmu Sastra. Jakarta: Pustaka Jaya, 2003.

[3] Y. Wulandari, "Kearifan Ekologis dalam Legenda Bujang Sembilan (Asal Usul Danau Maninjau)," J. Madah, vol. 8, no. 1, pp. 105-111, 2017.
[4] S. S. S. Umsyani, Rizma Aulia, Nensilianti, "Relasi Manusia dengan Nilai Kearifan Ekologis dalam Sastra Lisan Mantra Masyarakat Bugis:Kajian Ekokritik Glotfelty,” J. Sci. Humanit., vol. 1, no. 2, pp. 81-92, 2021.

[5] G. Gararad, Ecocritism: TheNew Critical Idiom. New York: Routledge, 2004.

[6] S. Endraswara, Ekokritik Sastra: Konsep Teori, dan Penerapannya. Yogyakarta: Morfolingua. Yogyakarta: Morfolingua, 2016.

[7] B. Gising, Kearifan Ekologis Tu Kajang Dalam Pengelolaan Hutan Adat Lestari Di Wilayah Adat Kajang Kabupaten Bulukumba. Disertasi. Makasar: Universitas Hasanudin, 2010.

[8] D.T. Patten, "The Role of Ecological Wisdom in Managing for Sustainable Interdependent Urban and Natural Ecosystems," Juournal Landsc. Urban Plan., vol. 1, no. 5, pp. 1-8.

[9] B. D. (eds) Naess, A., Allan D., Ecology of wisdom: writings by Arne Naess/edited by Alan Drengson and Bill Devall. Berkeley: Counterpoint., 2008.

[10] A. S. Keraf, Etika Lingkungan Hidup. Jakarta: Kompas, 2010.

[11] I. Johan, "Etnobiologi dan Keragaman Budaya di Indonesia," J. Umbara, vol. 1, no. 1, pp. 27-42, 2016.

[12] O. Madasari, Mata di Tanah Melus. Jakarta: Gramedia Pustaka, 2018.

[13] H. Poerwanto, Kebudayaan dan Lingkungan dalam Perspektif Antropologi. Yogyakarta: Pustaka Pelajar, 2005.

[14] T. Y. W. Subroto, "Koeksistensi alam dan budaya dalam arsitektur," ARTEKS J. Tek. Arsit., vol. 3, no. 2, pp. 1-8, 2019. 